
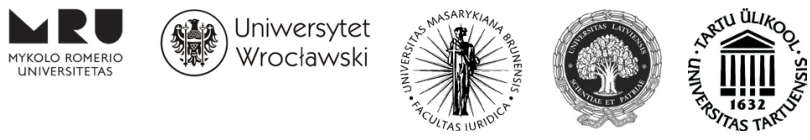

ISSN 1392-6195 (print) ISSN 2029-2058 (online) JURISPRUDENCIJA JURISPRUDENCE 2014, 21(4), p. 1186-1207.

\title{
LEGAL ISSUES OF THE PUBLIC ADMINISTRATION IN UKRAINE IN THE CONTEXT OF CONSTITUTIONAL AND PUBLIC ADMINISTRATION REFORMS
}

\author{
Yuliya Vashchenko \\ Taras Shevchenko National University of Kyiv, Faculty of Law, \\ Department of Administrative Law \\ Volodymyrska street, 64/13, 01601, Kyiv, Ukraine \\ Telephone: +380672892649 \\ E-mail: y_vashchenko@univ.kiev.ua \\ Received on 7 October, 2014; accepted on 20 November, 2014 \\ doi:10.13165/JUR-14-21-4-13
}

\section{Introduction}

The constitutional and public administration reforms are currently taking place in Ukraine. The legal issues of the system of central state bodies of executive power are among the most difficult problems. The Constitution of Ukraine does not stipulate the capable list of organizationally-legal forms of central bodies of executive power. It uses the general term "ministries and other central bodies of executive power". Therefore, the system of central bodies of executive power faced the strong political influence and was changed many times during the all stages of the public administration reform in Ukraine. Nowadays, the types of central bodies of executive power, their powers, and the relations with other state bodies are stipulated by the organic Law of Ukraine "On Central Bodies of Executive Power". The approval of this Law was a very important step within the public administration reform in Ukraine. However, the legal framework for the system of central bodies of executive power in Ukraine needs to be improved based on the theoretically proven concept. The legal

Jurisprudencija/Jurisprudence

(C) Mykolo Romerio universitetas, 2014

(C) Mykolas Romeris University, 2014
ISSN 1392-6195 (print), ISSN 2029-2058 (online) http://www.mruni.eu/lt/mokslo_darbai/jurisprudencija/ http://www.mruni.eu/en/mokslo_darbai/jurisprudencija/ 
nature, the organizationally-legal forms of entities of the public administration, in particular, of such special state bodies as central state bodies of executive power with special status and regulatory authorities, are among the most discussible issues. There is a separate group of bodies within the system of central state bodies of executive power that has the special scope of competence, special relations with the Government of Ukraine, the special procedure of establishment, reorganization and liquidation, as well as the special procedure of appointment and dismissal of the chairpersons of the bodies - central state bodies of executive power with special status. However, such bodies have a transitional character; their existence within the system of the bodies of executive power seems to be artificial. Therefore, it is necessary to analyze the legal nature of such bodies and to develop the recommendations regarding their place in the system of state bodies of Ukraine.

The legal status of independent regulatory authorities is another discussible issue of the public administration reform in Ukraine. Nowadays, there are the following independent regulatory authorities in Ukraine: National Energy and Utilities Regulatory Commission, National Connection and Informatization Regulatory Commission, National Financial Services Markets Regulatory Commission, National Securities and Stock Market Commission. These bodies have been excluded from the system of bodies of executive power. However, the legal status of such commissions needs to be improved. The Constitution of Ukraine does not include the provisions regarding these state bodies. The legal framework of such bodies is presented by the special laws of Ukraine that regulate the relations in certain economic spheres. The bodies mentioned above are established and liquidated by the President of Ukraine. The President of Ukraine also appoints and dismisses the chairpersons and the members of such bodies, as well as approves the regulations of these commissions. However, such powers of the President of Ukraine are not stipulated by the Constitution of Ukraine. Therefore, it is important to analyze the legal issues of such bodies and develop the recommendations regarding the enhancement of the legal status of independent regulatory authorities in Ukraine.

Therefore, in the following sections, the author examines the legal issues of the system of central bodies of executive power, as well as the legal status of independent regulatory authorities in Ukraine and presents the recommendations regarding the enhancement of the legislation of Ukraine regarding these issues.

\section{Central bodies of executive power in the system of public administration in Ukraine: legal issues in frames of the constitutional and public administration reforms}

There is a three-tier system of state bodies of executive power in Ukraine, according to the Constitution of Ukraine. This system consists of the Cabinet of 
Ministers of Ukraine (the highest body in the system of bodies of executive power), ministries and other central bodies of executive power (which represent the central level of the system), as well as the local bodies of executive power. It should be mentioned that the central level of the system of bodies of executive power faces the strongest political influence during all stages of the public administration reform in Ukraine. One of the possible reasons is that the Constitution of Ukraine does not stipulate the capable list of organizationally-legal forms of central bodies of executive power. It uses the general term "ministries and other central bodies of executive power". This formulation leads to the problems in the process of the organization and functioning of the system of central bodies of executive power. According to Article 92 of the Constitution of Ukraine, the organization and the functioning of the state bodies of executive power are stipulated exclusively by law. However, in reality this constitutional provision was ignored by the competent authorities for the longest time. The system of central bodies of executive power depended on the organ that was in charge of the establishment, reorganization and liquidation of such bodies, and this competent organ was not permanent. It should be stressed that the procedure of the establishment, reorganization and liquidation of the ministries and other central state bodies of executive power, as well as the procedure of the appointment and the dismissal of their management, depend on the form of state rule in Ukraine. According to the Constitution of Ukraine, in the reduction of 1996 Ukraine was a presidential-parliamentary republic. The ministries and other central bodies of executive power should be established, reorganized and liquidated by the President of Ukraine upon the recommendation of the Prime-minister of Ukraine (paragraph 15 of Article 106); ministers and chairpersons of other central bodies of executive power should be appointed upon the recommendation of the Primeminister of Ukraine and dismissed by the President of Ukraine (paragraph 10 of Article 106).

In accordance with the amendments to the Constitution of Ukraine made by Law of Ukraine "On Amendments to the Constitution of Ukraine" № 2222-IV of 08.12.2004 ${ }^{1}$, Ukraine became the parliamentary-presidential republic. The powers of the establishment, reorganization and liquidation of central bodies of executive power were transferred from the President of Ukraine to the Cabinet of Ministers of Ukraine. The ministers (with exemptions for the Minister of Foreign Affairs and the Minister of Defense) should be appointed upon the recommendation of the Prime-minister of Ukraine and dismissed by the Parliament of Ukraine; the Minister of Foreign Affairs and the Minister of Defense should be appointed upon the recommendation of the President of Ukraine (considering that the President of Ukraine represents Ukraine in international relations and is the commander-in-

1 Zakon Ukrai'iny "Pro zminy do Konstytutsi'i Ukrai'ny" [Law of Ukraine „Concerning changing of Ukraine Constitution“]. Vidomosti Verkhovnoi’ Rady Ukrai’ny. 2005, № 2. 
chief of the armed forces in Ukraine) and dismissed by the Parliament of Ukraine; the chairpersons of other central bodies of executive power should be appointed and dismissed upon the recommendation of the Prime-minister of Ukraine by the Cabinet of Ministers of Ukraine.

However, the Law on amendments to the Constitution of Ukraine mentioned above was declared unconstitutional by Decision of the Constitutional Court of Ukraine № 20-pா/2010 of 30.09.2010². Thus, constitutional reform of 2004 was terminated, Ukraine became presidential-parliamentary republic and, relatively, the powers of the establishment, reorganization and liquidation of the ministries and other central bodies of executive power, as well as the appointment and dismissal of the ministers and chairpersons of other central bodies of executive power, were returned to the President of Ukraine.

Considering the special political conditions in 2013-2014 years, the Constitution of Ukraine has been amended again. According to Law of Ukraine "On Revival of Some Provisions of the Constitution of Ukraine” № 742-VII of 21.02.2014³, Ukraine has become the parliamentary-presidential republic again. Thus, the establishment, reorganization and liquidation of the ministries and other central bodies of executive power, as well as the appointment and the dismissal of chairpersons of central bodies of executive power who are not members of the Cabinet of the Ministers of Ukraine upon the recommendation of the Prime-minister of Ukraine, are conducted by the Cabinet of the Ministers of Ukraine; the ministers (except the Minister of Foreign Affairs and the Minister of Defense) are appointed upon the recommendation of the Prime-minister of Ukraine and dismissed by the Verkhovna Rada of Ukraine; the Minister of Foreign Affairs and the Minister of Defense are appointed upon the recommendation of the President of Ukraine and dismissed by the Parliament of Ukraine.

The system of central bodies of executive power was not stable during the constitutional amendments mentioned above. Unfortunately, frequent changes of the organizationally-legal forms, the procedures of appointment and dismissal of

2 Rishennja Konstytucijnogo Sudu Ukrai'ny u spravi za konstytucijnym podannjam 252 narodnyh deputativ Ukrai'ny shchodo vidpovinosti Konstytutsii' Ukrai'ny (konstytutsijnosi) Zakonu Ukrai'ny "Pro vnesennha zmin do Konstytutsii' Ukrai'ny" vid 8 grudnja 2004 roku № 2222-IV (sprava pro doderzhannja procedury zmin do Konstytucii Ukrai’ny) [Solution of Ukrainian Constitutional Court concerning 252 constitutional application of public deputies of Ukraine concerning conformity of Ukraine Constitution (constitutionality) with Law of Ukraine „Concerning changing of Ukraine Constitution“ of 8th December'2004 No. 2222-IV (order of conformity of procedure of changing of Ukraine Constitution)] № 20-rp/2010 vid 30.09.2010. Oficijnyj Visnyk Ukrai'ny. 2010, № 72/1.

3 Zakon Ukrai'ny "Pro vidnovlennja dii' okremyh pologen' Konstytucii Ukrai'ny" [Law of Ukraine "Concerning implementation of the main statements of Ukraine Constitution"]. Vidomosti Verkhovnoi' Rady Ukrai'ny. 2014, № 11. 
their management, as well as of the powers of these bodies, were not based on the comprehensive theoretical concept.

It should be mentioned that the first attempt to define the basic principles of the organization of the system of central bodies of executive power was primarily provided in the Concept of Administrative Reform in Ukraine (hereinafter - the Concept) approved by Presidential Decree № 810/98 of 22.07.19984. According to this Concept, the central level of bodies of executive power was represented by the following organs:

- Ministries;

- State committees;

- Central bodies of executive power with special status.

According to the Concept, the ministries shall be responsible for the development and implementation of the policies in certain spheres of social life (sectors of state government). The ministries shall be governed by the ministers that are the members of the Cabinet of Ministers of Ukraine. Ministries have a dominant place among central bodies of executive power. State committees are central bodies of executive power that are not directly in charge of the policy development; they shall support to the ministries and the Government in the implementation of such policy by means of realization of state government functions (primarily inter-industrial or intersectoral character). The legal nature of the central bodies of executive power with special status is the most difficult to describe. It was just stipulated by the Concept that central bodies of executive power with special status can be in charge of the development and implementation of certain types of policies; the issues of their legal status and relations with other state bodies shall be regulated by special organic laws. However, the Concept does not stipulate what kind of state policies shall (or may) refer to the competence of the central bodies of executive power. In accordance with the Concept, there are two groups of central bodies of executive power with special status: 1) bodies defined by the Constitution of Ukraine; 2) bodies established by the special (organic) laws. As to the first group of central bodies of executive power with special status, it was proposed to include in this group constitutional bodies, such as the Antimonopoly Committee of Ukraine, the Public Property Found of Ukraine, the State Committee on Television and Broadcasting of Ukraine, as well as the Security Service of Ukraine. However, the Constitution of Ukraine does not include such type of central bodies of executive power with special status. It just prescribes special procedure of the appointment and the dismissal of the chairpersons of the bodies mentioned above. As to the second group of central bodies of executive power with special status - bodies established in accordance with organic laws - it should be reformy v Ukrai'ni" [Decree of President of Ukraine "Concerning the realization of conception of administration reform in Ukraine”]. Oficijnyi Visnyk Ukrainy. 1999, № 21. 
mentioned that for the longest period of time such bodies were established on the basis of Presidential or Governmental decisions (not on the basis of laws) and there were no strict criteria for providing some organ with the status of central bodies of executive power with special status. For instance, some time ago even the Ministry of Economy was among central bodies of executive power with special status.

Nowadays, the system of central bodies of executive power is defined by the special Law - Law of Ukraine “On Central State Bodies of Executive Power” № 3166VI of $17.03 .2011^{5}$. Considering that the framework for the organization and the activity of the state bodies of executive power shall be stipulated exclusively by law, the approval of this Law was a very important stage of the public administration reform in Ukraine. However, the system of central bodies of executive power provided by this Law is not comprehensive and needs to be enhanced.

First of all, according to this Law, the system of central bodies of executive power consists of the ministries and other central bodies of executive power. Thus, this provision is based on the constitutional formula. However, such approach is not reasonable. As Ukrainian researcher V. Averyanov stressed, the ministries are quite different in comparison with other central bodies of executive power since only ministers are members of the Cabinet of Ministers of Ukraine. Therefore, they should not be at the same level as other central state bodies of executive power ${ }^{6}$. Of course, relevant amendments have to be made in the Constitution of Ukraine. However, the Law mentioned above does not even define the ministries as main, leading bodies within the system of central bodies of executive power. The group of other central bodies of executive power consists of central bodies of executive power (services, agencies, inspections) and central bodies of executive power with special status. It should be mentioned that the Law does not include comprehensive criteria for the distinction of such types of the central bodies of executive power. For instance, the separation of services, agencies and inspections are provided on the basis of the scope of competence. The body shall be established as a service if the majority of its functions are the rendering of administrative services. The agencies are in charge of the public property management. Inspections shall perform control and supervisory functions. However, in practice the organizationally-legal form of "service" is used not only for the central state bodies of executive power. For instance, the Security Service of Ukraine is a state law-enforcement body of special purpose that encourages state security of Ukraine. This body is not included in the system of bodies of executive executive power bodies”]. Vidomosti Verkhovnoi' Rady Ukrai'ny. 2011, № 38.

6 Averyanov, V. Systema organiv vykonavchoi' vlady: utochnennja conceptual'nych zasad reformuvannja [Averyanov, V. System of executive governmental institutions: specification of conceptual principles of reformation], [interactive]. [accessed on 2014-10-16]. <http://nads. gov.ua/control/uk/publish/article;jsessionid=A058D14716D1C4B60C2708D9516E2310?a rt_id=37464\&cat_id=37402>. 
power. According to the legislation of Ukraine, the National Civil Service Agency of Ukraine is defined as a central body of executive power. However, this body is responsible for the development and realization of the state policy in the sphere of civil service, as well as for the functional government in the sphere of civil service in Ukraine (not for public property management) in accordance with the Regulation on National Civil Service Agency of Ukraine approved by the Decree of the Cabinet of Ministers of Ukraine № 500 of 01.10.2014 . The case of the National Civil Service Agency of Ukraine represents also another problem of distinction of ministries and other central bodies of executive power. According to the Law mentioned above, ministries are in charge of the development and the implementation of policies since other central bodies of executive power (except central bodies of executive power with special status) are responsible just for the realization of some functions of the implementation of certain policies. However, according to the Regulation of the National Civil Service Agency of Ukraine mentioned above, this body is responsible for the development and the realization of the state policy in the sphere of civil service.

The legal status of the central bodies of executive power with special status is one of the most problematic issues of the public administration reform in Ukraine. Central bodies of executive power with special status were introduced in the system of public administration of Ukraine in accordance with the Presidential Decrees of 15.12.1999 "On System of Central Bodies of Executive Power" № $1672^{8}$ and “On Changes in the Structure of Central Bodies of Executive Power" №1573. The attempt to define the key features of central bodies of executive power with special status was made in Presidential Decree № 1672. It was stipulated that this authority has special tasks and powers prescribed by the Constitution and the legislation of Ukraine; the special procedure of the establishment, reorganization, liquidation, subordination, accountability as well as the appointment and the dismissal of chairpersons and other issues can be stipulated for these bodies by the Constitution and the legislation. Therefore, the special tasks and powers are at the top place among the key features of the central bodies of executive power with special status. However, there are no peculiarities of the competence of such bodies in the Presidential Decree mentioned above or in other legal acts of Ukraine. Why some policy sectors shall be covered by the special bodies, not by the ministries? Unfortunately, there is no answer regarding

7 Postanova Kabinetu Ministriv Ukrai'ny "Pro zatverdgennja Pologennja pro Nacional'ne Agentstvo Ukrai'ny z pytan' dergavnoi' slugby" [Statement of Ukrainian Ministers Cabinet concerning validation of regulation of Ukrainian National Agency of State Service]. Oficijnyi Visnyk Ukrainy. 2014, № 81.

8 Ukaz Presydenta Ukrai'ny “Pro system central'nych organiv vykonavchoi' vlady” [Decree of President of Ukraine "Concerning system of executive power bodies"]. Oficijnyi Visnyk Ukrainy. 1999, №50.

9 Ukaz Presydenta Ukrai'ny "Pro zminy u strukturi central'nych organiv vykonavchoi' vlady" [Decree of President of Ukraine „Concerning changing of structure of central institutions of executive power“]. Oficijnyi Visnyk Ukrainy. 1999, №50. 
this question in the Administrative Law Science in Ukraine. Also, according to the Concept mentioned above, the legal status of the central bodies with special status shall be prescribed by the Constitution and laws of Ukraine. However, referring to this Presidential Decree, the issues of organization and the activity of such bodies shall be regulated by the legislation (that means not only by laws). Such provision was not in accordance with the Constitution of Ukraine.

Nowadays, the legal framework for central bodies of executive power is primarily defined in the Law of Ukraine "On Central Bodies of Executive Power". According to the provisions of Article 24 of this Law, there are two groups of central bodies of executive power with special status: 1) constitutional bodies, such as the Antimonopoly Committee of Ukraine, the Public Property Found of Ukraine, the State Committee of Television and Broadcasting of Ukraine; 2) other central bodies of executive power with special status established by the Cabinet of Ministers of Ukraine. Thus, these provisions of the Law are based on the model provided in the Concept of Administrative Reform mentioned above. Therefore, it should be stressed once more that there is no reason to include the constitutional bodies (from the first group) in the system of central bodies of executive power with special status. Concerning the second group - other central bodies of executive power with special status - there are no provisions in this Law regarding the peculiarities of their legal status (in particular, regarding the special competence, the procedures of their establishment, reorganization and liquidation, as well as the appointment and the dismissal of their chairpersons, etc.). Therefore, the legislative criteria for the distinction of such group of bodies of executive power as central bodies of executive power with special status are absent. Considering the Ukrainian experience, the main aim of the separation of this special group of bodies is the exclusion of such bodies from the direct Governmental control and establishment of the special relations of these bodies with other public authorities. For instance, some time ago the national commissions performing state regulation in certain economic sectors (such as energy sector, telecommunications, utilities, etc.) had a status of central bodies of executive power with special status. The author of this article supports the idea of the possibility of the existence in the system of state bodies of the public authorities that cannot be included in one of the "classical" braches of power (for instance, central banks, independent regulatory authorities). Therefore, it is recommended to liquidate such type of executive bodies as central bodies of executive power with special status in the system of public administration in Ukraine. As to the central bodies of executive power with special status that already exist, it is recommended to exclude from the system of bodies of executive power such bodies that cannot be directly subordinated to the Government due to the peculiarities of their competence (for example, the Antimonopoly Committee of Ukraine) and to provide other bodies that have the classical features of bodies of executive power with status of central bodies of executive power (for instance, the Public Property Found of Ukraine). Obviously, 
these changes have to be made on the basis of the comprehensive analysis of the legal nature of each central body of executive power with special status.

\section{Independent Regulatory Authorities as new actors in the system of the public administration in Ukraine: issues of the legal status}

The new actors have recently appeared in the system of public administration of Ukraine - national commissions performing state regulation in certain economic sectors. Nowadays, this group of organs is represented by the National Energy and Utilities Regulatory Commission, National Connection and Informatization Regulatory Commission, National Financial Services Markets Regulatory Commission, National Securities and Stock Market Commission. Legal status of these national regulatory commissions is prescribed by the laws and regulations of Ukraine. In accordance with laws of Ukraine (in particular, Article 11 of the Law of Ukraine "On Natural Monopolies", Article 6 of the Law of Ukraine "On State Regulation of Securities Market in Ukraine", Article 23 of the Law of Ukraine "On Financial Services and State Regulation of Financial Services Market in Ukraine", Article 17 of the Law of Ukraine "On Telecommunications"), national regulatory commissions in certain economic sectors have a status of state collegial bodies. Commission consists of the Chairperson and six members of the Commission.

These organs have a special place in the system of the public administration in Ukraine since they are not included in the system of bodies of executive power. Such approach is in line with the modern concept of the independent regulatory authorities developed by scholars and stipulated, in particular, by the EU legislation (for instance, in case of national regulatory authorities in energy and telecommunications sectors ${ }^{10}$ ) and national legislation of the EU Member States. However, the process of the establishment of the legal framework for the national regulatory commission has just begun in Ukraine. By the present moment, these regulatory authorities are outside the constitutional framework in Ukraine since the Constitution of Ukraine does not define such type of state bodies as state collegial bodies or national regulatory commissions. The President of Ukraine does not have powers to establish and liquidate such bodies, as well as to appoint and to dismiss the chairpersons and the members of these bodies, according to the Constitution of Ukraine. Such provisions are stipulated by the special laws mentioned above. However, it is not enough since the Constitution of Ukraine includes capable list of the Presidential powers. Also, there are no constitutional provisions regarding the relations of the national regulatory commissions with other state bodies.

As was presented above, the national regulatory commissions were included in the system of central bodies of executive power not very long time ago. Nowadays,

10 Vashchenko, Y. Energy Regulator in Ukraine: Legal Aspects of the Independence in the Light of the EU Requirements. Jurisprudence. 2014, 21(1): 185-203. 
some specialists still mistakenly think that these bodies are special types of central bodies of executive power. It should be mentioned that the national regulatory commissions presented within the group "ministries and institutions" on the official website of the Cabinet of Ministers of Ukraine that sometimes also leads to misunderstanding regarding the place of these bodies in the system of public authorities. This group primarily includes ministries and other central state bodies of executive power. Moreover, the group of national commissions on this website, besides the national regulatory commissions, includes the National Expert Commission for Protecting Public Morality. This organ is established in accordance with Law of Ukraine "On Protection of Public Morality" № 1296-IV of 20.11.2003"11 and has a status of permanent non-departmental public expert and control authority that acts in accordance with this Law and legislation of Ukraine, responsible for the encouragement of healthy lifestyle, adequate state of public morality, controls the turnover of the goods and entertainment events of sexual and erotic character. The members are appointed by the Cabinet of Ministers of Ukraine for the term of 5 years. The Government approves the regulation of the Commission. Therefore, the legal nature and the legal status of the National Expert Commission for Protecting Public Morality are quite different in comparison with national regulatory commissions. Thus, there is no reason to include this commission in the same group as national regulatory commissions and place them together with the central state bodies of executive power.

The legislation of Ukraine does not include comprehensive provisions on relations of the national regulatory commissions with the Government of Ukraine. However, it is stipulated that the national regulatory commissions act, in particular, on the basis of the regulations of the Cabinet of Ministers of Ukraine; the chairperson of the regulatory commission represents the interests of the commission in the Cabinet of Ministers of Ukraine and has a right to participate in the meetings of the Cabinet of Ministers of Ukraine with a right to a deliberative vote. Moreover, according to the Regulation of the Cabinet of Ministers of Ukraine approved by Regulation of the Cabinet of Ministers of Ukraine № 950 of $18.07 .2007^{12}$, the chairpersons of the state collegial bodies can be included in the governmental committee. Regulations of the National Energy and Utilities Regulatory Commission approved by Order of the National Energy and Utilities Regulatory Commission № 3 of 17.09.2014 ${ }^{13}$ even

11 Zakon Ukrainy "Pro zakhyst suspilnoyi morali” [Law of Ukraine „Concerning the defense of morality“]. Vidomosti Verkhovnoi Rady Ukrai’ny. 2004, № 14.

12 Postanova Kabinetu Ministriv Ukrai'ny "Pro zatverdgennja Reglamentu Kabinetu Ministriv Ukrai'ny" [Statement of Ukrainian Ministers Cabinet concerning validation of regulation of Ukrainian Ministers Cabinet]. Oficijnyi Visnyk Ukrai'ny. 2007, № 54.

13 Nakaz Nacional'noi' komisii', shcho zdi'snyuye dergavne regulyuvannja u sferah energetyky ta komunal'nyh poslug "Pro zatverdgennja Reglamentu Nacional'noi' komisii', shcho zdi'snyuye dergavne regulyuvannja u sferah energetyky ta komunal'nyh poslug” [Statement of National 
prescribe that the commission can act in accordance with the instructions of the Cabinet of Ministers of Ukraine.

Concerning the relations of the national regulatory commissions with the President of Ukraine, it should be stressed that in accordance with special laws mentioned above such national regulatory commissions are subordinated to the President of Ukraine. The President of Ukraine appoints and dismisses the chairpersons and the member of these commissions. The national regulatory commissions act on the basis of the regulations approved by the President of Ukraine. The President of Ukraine also approves the maximum number of the staff of the Commission.

The relations of subordination traditionally mean the strongest degree of the dependence of one entity on another. Obviously, such type of relations is inconsistent with the legal nature of the independent regulatory authority. For instance, in part of the energy regulator it is not in compliance with the EU energy legislation. In particular, pursuant to Article 35 of Directive 2009/72/EC and Article 39 of Directive 2009/73/EC, the Member States shall guarantee the independence of the regulatory authority and shall ensure that it exercises its powers impartially and transparently. With regard to the organizational independence, the Member States shall ensure, in particular, that the regulator is legally distinct and functionally independent from any public entity; its staff and the persons responsible for its management do not seek or take direct instructions from any government of other public entity when carrying out the regulatory tasks. The Member States shall ensure that the regulatory authority can take autonomous decisions, independently from any political body ${ }^{14}$. Ukraine shall fulfill these requirements as a full-fledged member of the Energy Community. Such obligations are also defined by the EU-Ukraine Association Agreement that was ratified by Law of Ukraine of 16.09.2014 № 1678-VII.

It is important also to analyze another state of relations of the national regulatory commissions - accountability. In accordance with the laws mentioned above, the national regulatory commissions are accountable to the Ukrainian Parliament - the Verkhovna Rada of Ukraine. However, according to the Regulation of the National Energy and Utilities Regulatory Commission approved by Presidential Decree № 715/2014 of 10.09.2014 ${ }^{15}$, the Commission submits the annual report on the results of its activity to the President of Ukraine, to the Verkhovna Rada of Ukraine, as well

Committee of modern governmental regulation in energy and utility services fields concerning the validation of regulation of National Committee of Modern governmental regulation in energy and utility services fields], [interactive]. [accessed on 2014-10-16]. <http://www.nerc. gov.ua/?id=11775>.

14 Vashchenko, Y. Energy Regulator in Ukraine: Legal Aspects of the Independence in the Light of the EU Requirements. Jurisprudence. 2014, 21(1): 185-203.

15 Ukaz Presidenta Ukrai'ny "Pro zanverdgennja Pologennja pro Nacional'nu komisiyu, shcho zdiysnyuye dergavne regulyuvannja u sferach energetyky ta komunalnych poslug" [Decree of President of Ukraine „Concerning validation of statute of National Committee of governmental regulation in energy and utility services fields“]. Oficijnyi Visnyk Ukrai’ny. 2014, № 74. 
as represents this report on its website. The Regulation on National Financial Services Markets Regulatory Commission approved by Presidential Decree № 1070/2011 of 23.11.2011 ${ }^{16}$ just stipulates that the Commission promulgates in the official media the main provisions of its annual report. There is no special provision on accountability of the National Connection and Informatization Regulatory Commission in the Regulation approved by Presidential Decree № 1067/2011 of 23.11.2011 ${ }^{17}$. However, in accordance with the Law of Ukraine "On Telecommunications", the Commission publishes the annual reports on the Commission's activity on the official website until April 1 of the next year. Nevertheless, there are no special provisions regarding the submission of the reports to the Verkhovna Rada of Ukraine (or to the President of Ukraine). The Law of Ukraine "On State Regulation of Securities Market in Ukraine" and the Regulation on the National Securities and Stock Market Commission approved by Presidential Decree № 1063/2011 of $23.11 .2011^{18}$ do not include the provisions regarding the preparation an submission of the annual reports of the Commission. It should be mentioned that there are different approaches to the accountability of the independent regulatory authorities in foreign countries, too. For instance, in Lithuania the chairperson of the Commission for Prices and Energy submits annual reports to the President, the Seimas and the Government, whereas the Bank of Lithuania and Radio and Television Commission are accountable to the Parliament ${ }^{19}$. However, the accountability requirements and procedures shall be strictly defined by laws. Therefore, the legislative provisions on the accountability of the national regulatory authorities need to be improved by means of establishment of strict requirements for such procedure (in particular to define the terms of submission of such reports, the requirements on the content of reports, the procedure of the consideration of the reports, as well as the types of possible decisions regarding the consideration of such reports).

One of the very important issues in the light of the relations of the national regulatory commissions with other public authorities is the participation of the national regulatory commissions in the process of the development of draft laws

16 Ukaz Presydenta Ukrai'ny "Pro Nacional'nu Komisiyu, shcho zdiysnyuye derganve regulyuvannja u sferi rynkiv finansovyh poslug" [Decree of President of Ukraine "Concerning National Commission of state regulation in financial services market field"]. Oficijnyi Visnyk Ukrai'ny. 2011, № 94.

17 Ukaz Presydenta Ukrai'ny "Pro Nacional'nu Komisiyu, shcho zdiysnyuye derganve regulyuvannja u sferi zv'yazku ta informatyzacii" [Decree of President of Ukraine "Concerning National Commission of state regulation in communication and information fields"]. Oficijnyi Visnyk Ukrai'ny. 2011, № 94.

18 Ukaz Presydenta Ukrai'ny "Pro Nacional'nu Komisiyu z cinnych paperiv ta fondovogo rynku" [Decree of President of Ukraine "Concerning National Commission of obligations and funds market”]. Oficijnyi Visnyk Ukrai'ny. 2011, № 94.

19 Pūraite, A.; Deviantikovaitè, I. Independent Regulatory and Administrative Authorities in the Republic of Lithuania. International Journal for Legal Research. 2013, 4: 283-295. 
and regulations. Referring to the special laws, in particular to Law of Ukraine "On Natural Monopolies" (Article 14), national regulatory commissions shall approve the normative legal acts. There is a problem of independence of regulatory commissions in part of these tasks since the normative acts of the commissions (with some exceptions) are subject to the procedure of state registration conducted by the Ministry of Justice of Ukraine. According to Article 50 of Law of Ukraine "On Cabinet of Ministers of Ukraine № 794-VIII of 27.02.201420, state collegial bodies have a right to initiative of approval of acts of the Cabinet Ministers of Ukraine. State collegial bodies develop the draft Governmental regulations and introduce such drafts to the Cabinet of Ministers of Ukraine. Similar provisions are prescribed in the Regulation of the Cabinet of Ministers of Ukraine (in paragraphs 32, 48). As to the participation of the state collegial bodies in the process of the development, consideration and introduction of the draft laws, it should be stressed that there is a gap in Ukrainian legislation regarding this issue. According to the Constitution of Ukraine (Article 93), the President of Ukraine, the People's Deputies of Ukraine and the Cabinet of Ministers of Ukraine have a right of legislative initiative. Thus, national regulatory commissions can participate in the legislative process indirectly, via one of the subjects of legislative initiative mentioned above. However, the procedure of such participation shall be prescribed by law. It should be mentioned that there is no special provisions regarding the procedure of the participation of the regulatory commissions in legislative process in laws of Ukraine. Considering that national regulatory commissions are subordinated to the President of Ukraine in accordance with the laws of Ukraine, it seems more logically that the regulatory commissions can introduce the draft laws via the President of Ukraine. However, the legislation of Ukraine includes different provisions regarding the participation of the national regulatory commissions in the process of the development and the consideration of the draft laws. For instance, according to the Regulation on the National Securities and Stock Market Commission approved by Presidential Decree № 1063/2011 of 23.11.2011 ${ }^{21}$, the Commission submits the draft laws and acts of the President of Ukraine developed by the Commission to the President of Ukraine and the Cabinet of Ministers of Ukraine. The similar provision is prescribed by the Regulation on National Financial Services Markets Regulatory Commission approved by Presidential Decree № 1070/2011 of 23.11.201122. Referring to the Regulation

20 Zakon Ukrai'ny "Pro Kabinet Ministriv Ukrai'ny” [Law of Ukraine „Concerning Ministers Cabinet of Ukraine“]. Vidomosti Verkhovnoi’ Rady Ukrai'ny. 2014, № 13.

21 Ukaz Presydenta Ukrai'ny "Pro Nacional'nu Komisiyu z cinnych paperiv ta fondovogo rynku" [Decree of President of Ukraine "Concerning National Commission of obligations and funds market”]. Oficijnyi Visnyk Ukrai’ny. 2011, № 94.

22 Ukaz Presydenta Ukrai'ny "Pro Nacional'nu Komisiyu, shcho zdiysnyuye derganve regulyuvannja u sferi rynkiv finansovyh poslug" [Decree of President of Ukraine "Concerning National Commission of state regulation in financial services market field"]. Oficijnyi Visnyk Ukrai'ny. 2011, № 94. 
on National Connection and Informatization Regulatory Commission approved by Presidential Decree № 1067/2011 of 23.11.2011 ${ }^{23}$, the Commission submits the proposals on draft laws and other normative legal acts to the President of Ukraine and the Cabinet of Ministers of Ukraine for the consideration.

It should be mentioned that different wording is used in the Regulation of the National Energy and Utilities Regulatory Commission approved by Presidential Decree № 715/2014 of 10.09.2014. According to this act, the Commission summarizes the practice of the implementation of the legislation, develops and submits the proposals on the enhancement of the legislation in accordance with the defined procedure. For instance, the draft Law "On State Regulation in Energy Sector of Ukraine" was developed by the National Energy Regulatory Commission according to the Announcement on the promulgation of Draft Regulatory Act - the Law of Ukraine "On State Regulation in Energy Sector of Ukraine" of 10.04.2013 This Draft Law was introduced by the Chairman of the National Energy Regulatory Commission Sergii Titenko during the meeting of the Cabinet of Ministers of Ukraine on 24.07.2013 ${ }^{25}$ and was introduced by the Cabinet of Ministers of Ukraine and registered in the Parliament of Ukraine on 15.08.2013 ${ }^{26}$ (register number 3095) ${ }^{27}$.

However, the Regulation of the Cabinet of Ministers of Ukraine mentioned above does not define the state collegial bodies as subjects authorized to introduce the draft laws to the Cabinet of Ministers of Ukraine. Such provision can be found, in particular, in the Regulation of the National Energy and Utilities Regulatory Commission mentioned above. It is stipulated that the Commission cooperates with the Secretariat of the Cabinet of Ministers of Ukraine on issues connected with the relations with the Cabinet of Ministers of Ukraine, conducts consultations regarding the procedure of the development of the draft legal acts and other documents introduced for the consideration to the Cabinet of Ministers of Ukraine. Moreover, it is prescribed that the Commission encourages the presentation of the draft

23 Ukaz Presydenta Ukrai'ny "Pro Nacional'nu Komisiyu, shcho zdiysnyuye derganve regulyuvannja u sferi zv'yazku ta informatyzacii" [Decree of President of Ukraine "Concerning National Commission of state regulation in communication and information fields"]. Oficijnyi Visnyk Ukrai'ny. 2011, № 94.

24 Povidomlennja pro oprylyudnennja proektu regulyatornogo aktu - Zakonu Ukrai'ny "Pro dergavne regulyuvannja v energetyci Ukrai'ny" [Announcement in regard of the project of law of Ukraine „Concerning governmental administration of energy of Ukraine“] [interactive]. [accessed on 2014-10-16]. <http://www3.nerc.gov.ua/index.php?news=3186>. Agenda of the Cabinet of Ministers of Ukraine Meeting for 24.07.2013 [interactive]. [accessed on 2014-10-16]. <http://www.kmu.gov.ua/control/uk/meetings/agenda?mid=246538308>.

26 This Law was recalled on 27.02.2014.

27 Proekt Zakonu Ukrai'ny "Pro dergavne regulyuvannja v sferi energetyky Ukrai'ny" [Project of Law of Ukraine - law of Ukraine „Concerning governmental administration of energy of Ukraine“] 2013 [interactive]. [accessed on 2014-10-16]. <http://w1.c1.rada.gov.ua/pls/zweb2/ webproc4_1?pf 3511=48044>. 
Law introduced by the Cabinet of Ministers of Ukraine in the Verkhovna Rada of Ukraine, as well as its support at all stages of the consideration in cases defined in the Regulation of the Cabinet of Ministers of Ukraine. However, as it was already mentioned, the Regulation of the Cabinet of Ministers of Ukraine does not include such provisions. Therefore, in practice, the relevant provisions of the Regulation of the Cabinet of Ministers of Ukraine regarding the participation of the state executive bodies in the process of the development and the consideration of the draft laws unreasonably apply to the participation in this process of the national regulatory commissions.

Therefore, the procedure of the participation of state collegial bodies in the legislative process requires special research in order to develop the comprehensive recommendations on the enhancement of Ukrainian legislation regarding this issue. As to the author's opinion, the independent regulatory authorities should be granted the constitutional right to legislative initiative in order to encourage the adequate participation of these bodies in the legislative procedure and to strengthen the expert component of this process.

Also, it should be mentioned that the legislation in Ukraine does not define the procedure of the reorganization and the liquidation of the state collegial bodies. The recent changes in the legal status of the energy regulator in Ukraine are the bright sample of this problem. Thus, according to the Presidential Decrees of 27 August 2014, the National Commission Performing State Regulation in the Energy Sphere (NERC) and the National Commission Performing State Regulation in the Utilities Sphere were liquidated and the National Commission Performing State Regulation in the Spheres of Energy and Utilities (NKREKP) was established. The chairpersons and the members of the former regulators were dismissed and the chairperson and the members of the new regulator were appointed by the President of Ukraine. It shall be stressed that according to the Law of Ukraine "On Natural Monopolies" (Article 11) the term of office of the chairperson and the member of the Commission is six years; the start of the presidency of the newly elected President of Ukraine cannot be a reason for the dismissal of the chairperson and the member of the Commission. Moreover, such Presidential decisions are not in compliance with the main principle of the independence of the energy regulator stipulated by the European Union Legislation that Ukraine shall implement as a full-fledged member of the Energy Community and in accordance with the EU-Ukraine Association Agreement. It should be mentioned that the conclusion on the liquidation of the NERC and the establishment of the NKREKP placed on the official website of the Energy Community is quite negative in part of the independence of the energy regulator in Ukraine. It is stressed that "Repeated now for the $2^{\text {nd }}$ time, the procedure goes hand in hand with the dismissal of (most) Commissioners in office. It raises serious concerns in terms of political intervention in the management of the regulator and openly circumvents the Third Energy Package requirements that limit dismissal of the regulator's managements 
exclusively to incompliance of Board members with independence rules. NERC's Board members did not take any incompliant action. Quite on the contrary, the liquidation and re-establishment of public bodies appears to be a common approach in Ukraine with the sole purpose of replacing the management. Such methods are in clear violation to the Energy Community 'acquis' and should be abolished." ${ }^{28}$

Therefore, the legal framework of the national regulatory commissions in Ukraine needs to be improved. First of all, the main issues of the legal status of such bodies shall be stipulated by the Constitution of Ukraine. The necessity of the constitutional regulation of these issues is supported by scholars from other countries $^{29}$. Recent legislative initiatives in Ukraine have demonstrated that the President of Ukraine is familiar with the problem of the constitutional status of the national regulatory commissions. Thus, the Presidential Draft Law of Ukraine "On Changes to the Constitution of Ukraine (regarding the responsibilities of the state bodies and self-government bodies) № 4178a was registered by the Verkhovna Rada of Ukraine on July 26,2014 . The proposed changes, in particular, were devoted to the legal status of national commissions performing state regulation in the spheres of natural monopolies, communication and informatization, securities and financial services markets. According to Article 106 (p. $9^{2}$ ), in the wording of this Draft Law, the chairpersons and the members of such regulatory commissions shall be appointed and dismissed solely by the President of Ukraine. However, to the author's opinion, the legislative provisions regarding the subordination of the national regulatory authorities to the President of Ukraine, the sole powers of the President of Ukraine to establish and to liquidate the national regulatory authorities, to appoint and to dismiss the chairpersons and the members of such bodies as well as to regulate their activities by means of Presidential legal acts are inconsistent with the principle of independence of national regulatory authorities. Therefore, it is thought that the appointment and the removal from office of the chairpersons and the members of such bodies shall be conducted jointly by the Parliament of Ukraine and by the President of Ukraine ${ }^{30}$. The Constitution of Ukraine shall include also provisions regarding the organizationallylegal forms of such bodies, the establishment, reorganization and liquidation, the relations of the national regulatory authorities with the Parliament of Ukraine, the President of Ukraine and the Government of Ukraine, as well as the necessity of the approval of special organic law (laws) on national regulatory authorities.

28 Ukraine Regulatory Authority. Energy Community [interactive]. [accessed on 2014-10-16]. <http://www.energy-community.org/portal/page/portal/ENC_HOME/AREAS_OF_WORK/ Implementation/Ukraine/Regulatory_Authority>.

29 Musa, A.; Kopric, I. What Kind of Agencification in Croatia? Trends and Future Directions. Transylvanian Review of Administrative Science. Special Issue: 33-53 [interactive]. [accessed on 08-02-2014]. <http://rtsa.ro/en/files/TRAS-35E-SI-4-MUSA,\%20KOPRIC.pdf >.

30 Vashchenko, Y. Energy Regulator in Ukraine: Legal Aspects of the Independence in the Light of the EU Requirements. Jurisprudence. 2014, 21(1): 185-203. 


\section{Conclusions}

The system of the public administration in Ukraine needs to be improved based on the theoretically proven concept. Based on the analysis conducted in this paper, it is recommended to establish relevant criteria for the distinction of different organizationally-legal forms of central state bodies of executive power.

There is a separate group of bodies within the system of central state bodies of executive power that has the special scope of competence, special relations with the Government of Ukraine, the special procedure of establishment, reorganization and liquidation, as well as the special procedure of appointment and dismissal of the chairmen of the bodies - central state bodies of executive power with special status. However, such bodies have a transitional character; their existence within the system of the bodies of executive power seems to be artificial. Therefore, it is recommended to exclude such bodies from the system of bodies of executive power. As to the central bodies of executive power with special status that already exist, it is recommended to exclude from the system of bodies of executive power such bodies that cannot be directly subordinated to the Government due to the peculiarities of their competence (for example, the Antimonopoly Committee of Ukraine) and to provide other bodies that have the classical features of bodies of executive power with status of central bodies of executive power (for instance, the Public Property Fund of Ukraine). Obviously, these changes have to be made on the basis of the comprehensive analysis of the legal nature of each central body of executive power with special status.

The author of this paper supports the establishment of the separate group of independent regulatory authorities (that should include, in particular, the Antimonopoly Committee of Ukraine, regulatory commissions in the spheres of energy, utilities, telecommunications, bonds and financial markets) within the system of public administration of Ukraine. However, the legal framework for such regulatory authorities is still stipulated only by laws and regulations. Therefore, it is proposed to amend the Constitution of Ukraine with provisions on independent regulatory authorities, and, in particular, to share the responsibilities regarding the appointment and dismissal of the chairmen and the members of such bodies between the Parliament and the President of Ukraine, to stipulate that the framework for establishment and functioning of these organs shall be stated only by laws of Ukraine, to define that the regulatory bodies shall be accountable to the Parliament of Ukraine and to the President of Ukraine. The legislative provisions on the accountability of the national regulatory authorities need to be improved by means of establishment of strict requirements for such procedure (in particular to define the terms of submission of such reports, the requirements on the content of reports, the procedure of the consideration of the reports, as well as the types of possible decisions regarding the consideration of such reports). Based on the analysis provided in this paper, the author came to the conclusion that the independent regulatory authorities should 
be granted the constitutional right to legislative initiative in order to encourage the adequate participation of these bodies in the legislative procedure and to strengthen the expert component of this process.

\section{References}

Agenda of the Cabinet of Ministers of Ukraine Meeting for 24.07.2013 [interactive]. [accessed on 201410-16]. <http://www.kmu.gov.ua/ control/uk/meetings/agenda? $\mathrm{mid}=$ 246538308>.

Averyanov, V. Systema organiv vykonavchoi' vlady: utochnennja conceptual'nych zasad reformuvannja [Averyanov, V. System of executive governmental institutions: specification of conceptual principles of reformation], [interactive]. [accessed on 2014-10-16]. <http://nads.gov.ua/ control/uk/publish/article;jsessionid= A058D14716D1C4B60C2708D9516E 2310?art_id $=37464 \&$ cat_id $=37402>$.

Musa, A.; Kopric, I. What Kind of Agencification in Croatia? Trends and Future Directions. Transylvanian Review of Administrative Science. Special Issue: 33-53 [interactive]. [accessed on 08-02-2014]. <http:// rtsa.ro/en/files/TRAS-35E-SI-4MUSA,\%20KOPRIC.pdf>.

Nakaz Nacional'noi' komisii', shcho zdi'snyuye dergavne regulyuvannja u sferah energetyky ta komunal'nyh poslug "Pro zatverdgennja Reglamentu Nacional'noi' komisii', shcho zdi'snyuye dergavne regulyuvannja u sferah energetyky ta komunal'nyh poslug" [Statement of National Committee of modern governmental regulation in energy and utility services fields concerning the validation of regulation of National Committee of Modern governmental regulation in energy and utility services fields], [interactive]. [accessed on 201410-16]. <http://www.nerc.gov.ua/ ?id= $11775>$.

Nakaz Nacional'noi' komisii', shchozdi'snyuye dergavne regulyuvannja u sferah energetyky ta komunal'nyh poslug "Pro zatverdgennja Reglamentu Nacional'noi' komisii', shchozdi'snyuye dergavne regulyuvannja $u$ sferah energetyky ta komunal'nyh poslug" [Statement of National Committee of modern governmental regulation in energy and utility services fields concerning the validation of regulation of National Committee of Modern governmental regulation in energy and utility services fields], [interactive]. [accessed on 2014-10-16]. <http:// www.nerc.gov.ua/?id=11775>.

Postanova Kabinetu Ministriv Ukrai'ny "Pro zatverdgennja Pologennja pro Nacional'ne Agentstvo Ukrai'ny $\mathrm{z}$ pytan' dergavnoi' slugby" [Statement of Ukrainian Ministers Cabinet concerning validation of regulation of Ukrainian National Agency of State Service]. Oficijnyi Visnyk Ukrainy. 2014, № 81.

Postanova Kabinetu Ministriv Ukrai'ny "Pro zatverdgennja Reglamentu Kabinetu Ministriv Ukrai'ny" [Statement of Ukrainian Ministers Cabinet concerning validation of 
regulation of Ukrainian Ministers Cabinet ]. Oficijnyi Visnyk Ukrai'ny. 2007, № 54 .

Povidomlennja pro oprylyudnennja proektu regulyatornogo aktu Zakonu Ukrai'ny "Pro dergavne regulyuvannja v energetyci Ukrai'ny" [Announcement in regard of the project of law of Ukraine „Concerning governmental administration of energy of Ukraine"], [interactive]. [accessed on 2014-10-16]. <http:// www3. nerc.gov.ua/index.php?news= 3186>.

Proekt Zakonu Ukrai'ny “Pro dergavne regulyuvannja $\mathrm{V}$ sferi energetyky Ukrai'ny”. 2013 [interactive]. [accessed on 2014-10-16]. <http://w1.c1. rada.gov.ua/pls/zweb2/webproc4 1 ?pf3511=48044>.

Pūraitè, A.; Deviantikovaitè, I. Independent Regulatory and Administrative Authorities in the Republic of Lithuania. International Journal for Legal Research. 2013, 4: 283-295.

Rishennja Konstytucijnogo Sudu Ukrai'ny u spravi za konstytucijnym podannjam 252 narodnyh deputativ Ukrai'ny shchodo vidpovinosti Konstytutsii' Ukrai'ny (konstytutsijnosi) Zakonu Ukrai'ny "Pro vnesennha zmin do Konstytutsii' Ukrai'ny” vid 8 grudnja 2004 roku № 2222-IV (sprava pro doderzhannja procedury zmin do Konstytucii Ukrai'ny) [Solution of Ukrainian Constitutional Court concerning 252 constitutional application of public deputies of Ukraine concerning conformity of Ukraine Constitution (constitutionality) with Law of Ukraine „Concerning changing of Ukraine Constitution" of 8th December'2004 No. 2222-IV (order of conformity of procedure of changing of Ukraine Constitution)], № 20-rp/2010 vid 30.09.2010. Oficijnyj Visnyk Ukrai'ny. 2010, № 72/1.

Ukaz Presidenta Ukrai'ny "Pro zanverdgennja Pologennja pro Nacional'nu komisiyu, shchozdiysnyuye dergavne regulyuvannja $\mathrm{u}$ sferach energetyky ta komunalnych poslug" [Decree of President of Ukraine "Concerning validation of statute of National Committee of governmental regulation in energy and utility services fields"]. Oficijnyi Visnyk Ukrai'ny. 2014, № 74.

Ukaz Presydenta Ukrai'ny “Pro Nacional'nu Komisiyu $\mathrm{z}$ cinnych paperiv ta fondovogo rynku" [Decree of President of Ukraine "Concerning National Commission of obligations and funds market"] . Oficijnyi Visnyk Ukrai'ny. 2011, № 94.

Ukaz Presydenta Ukrai'ny "Pro Nacional'nu Komisiyu, shcho zdiysnyuye derganve regulyuvannja u sferi rynkiv finansovyh poslug" [Decree of President of Ukraine "Concerning National Commission of state regulation in financial services market field"]. Oficijnyi Visnyk Ukrainy. 2011, № 94.

Ukaz Presydenta Ukrai'ny "Pro Nacional'nu Komisiyu, shcho zdiysnyuye derganve regulyuvannja u sferi rynkiv finansovyh poslug" [Decree of President of Ukraine "Concerning National Commission of state regulation in financial services market field"]. Oficijnyi Visnyk Ukrai'ny. 2011, № 94.

Ukaz Presydenta Ukrai'ny "Pro system central'nych organiv vykonavchoi' 
vlady" [Decree of President of Ukraine "Concerning system of executive power bodies"]. Oficijnyi Visnyk Ukrainy. 1999, №50.

Ukaz Presydenta Ukrai'ny "Pro zakhody shchodo vprovadgennya Kontseptsii administratyvnoi' reformy v Ukrai'ni" [Decree of President of Ukraine "Concerning the realization of conception of administration reform in Ukraine"]. Oficijnyi Visnyk Ukrainy. 1999, № 21.

Ukaz Presydenta Ukrai'ny "Pro zminy u strukturi central'nych organiv vykonavchoi' vlady" [Decree of President of Ukraine "Concerning changing of structure of central institutions of executive power"]. Oficijnyi Visnyk Ukrainy. 1999, №50.

Ukraine Regulatory Authority. Energy Community [interactive]. [accessed on 2014-10-16]. <http://www. energycommunity.org/portal/page/ portal/ENC_HOME/AREAS_OF_ WORK/Implementation/Ukraine/ Regulatory_Authority $>$.

Vashchenko, Y. Energy Regulator in Ukraine: Legal Aspects of the Independence in the Light of the EU
Requirements. Jurisprudence. 2014, 21(1): 185-203.

Zakon Ukrai'iny "Pro zminy do Konstytutsi'i Ukrai'ny" [Law of Ukraine "Concerning changing of Ukraine Constitution"]. Vidomosti Verkhovnoi' Rady Ukrai'ny. 2005, № 2. Zakon Ukrai'ny "Pro central'ni organy vykonavchoi" vlady" [Law of Ukraine "Concerning executive power bodies"]. Vidomosti Verkhovnoi' Rady Ukrai'ny. 2011, № 38.

Zakon Ukrai'ny "Pro Kabinet Ministriv Ukrai'ny" [Law of Ukraine "Concerning Ministers Cabinet of Ukraine“]. Vidomosti Verkhovnoi' Rady Ukrai'ny. 2014, № 13.

Zakon Ukrai'ny "Pro vidnovlennja dii' okremyh pologen' Konstytucii Ukrai'ny" [Law of Ukraine "Concerning implementation of the main statements of Ukraine Constitution"]. Vidomosti Verkhovnoi" Rady Ukrai'ny. 2014, № 11.

Zakon Ukrainy "Pro zakhyst suspilnoyi morali” [Law of Ukraine „Concerning the defense of morality"]. Vidomosti Verkhovnoi Rady Ukrainy. 2004, № 14.

\title{
VIEŠOJO ADMINISTRAVIMO UKRAINOJE TEISINĖS PROBLEMOS KONSTITUCINÉS IR VIEŠOJO ADMINISTRAVIMO REFORMŲ KONTEKSTE
}

\author{
Yuliya Vashchenko \\ Kijevo nacionalinis Taraso Ševčenkos universitetas, Ukraina
}

Anotacija. Šiame straipsnyje tiriami teisiniai Ukrainos viešojo administravimo sistemos aspektai konstituciniu ir administraciniu reformu, kurios bütinos integraci-

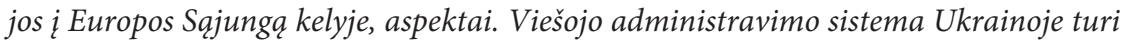


būti tobulinama remiantis mokslinès teorijos patikrintomis koncepcijomis. Straipsnyje analizuojamos viešojo administravimo subjektu, tarp ju ir specialiu igaliojimu turinčiu subjektu, ir vykdomosios valdžios institucijų, ir nepriklausomu reguliaciniu institucijų, teisine prigimtis, teisinès organizacinés formos. Remiantis šiame straipsnyje atlikta analize pateikiamos išvados dèl skirtingu centriniu vykdomosios valdžios instituciju organizaciniu teisiniu formu atitinkamu kriteriju nustatymo.

Reikšminiai žodžiai: viešasis administravimas, konstitucine reforma, viešojo administravimo reforma, vykdomosios valdžios institucijos, nepriklausomos reguliacines institucijos.

\title{
LEGAL ISSUES OF THE PUBLIC ADMINISTRATION IN UKRAINE IN THE CONTEXT OF CONSTITUTIONAL AND PUBLIC ADMINISTRATION REFORMS
}

\author{
Yuliya Vashchenko \\ Taras Shevchenko National University of Kyiv, Ukraine
}

Summary. The system of the public administration in Ukraine needs to be improved based on the theoretically proven concept. The legal nature, the organizationally-legal forms of entities of the public administration, in particular, of such special state bodies as central state bodies of executive power with special status and national regulatory authorities, are among the most discussible issues. Based on the analysis conducted in this paper, the conclusion about the necessity of the relevant criteria for the establishment of different organizationally-legal forms of central state bodies of executive power has been made. There is a separate group of bodies within the system of central state bodies of executive power that has the special scope of competence, special relations with the Government of Ukraine, the special procedure of establishment, reorganization and liquidation, as well as the special procedure of appointment and dismissal of the chairmen of the bodies - central state bodies of executive power with special status. However, such bodies have a transitional character; their existence within the system of the bodies of executive power seems to be artificial. Therefore, it is recommended to exclude such bodies from the system of bodies of executive power. The author of this paper supports the establishment of the separate group of independent regulatory authorities (that should include, in particular, the Antimonopoly Committee of Ukraine, regulatory commissions in the spheres of energy, utilities, telecommunications, bonds and financial markets) within the system of the public administration of Ukraine. However, the legal framework for such national regulatory authorities is still stipulated only by laws and regulations. Therefore, it is proposed to amend the Constitution of Ukraine with the provisions on independent regulatory authorities, and, in particular, to share the responsibilities regarding the appointment and dismissal of the chairmen 
and the members of such bodies between the Parliament and the President of Ukraine, to stipulate that the framework for establishment and functioning of these organs shall be stated only by laws of Ukraine, to define that the national regulatory bodies shall be accountable to the Parliament of Ukraine and to the President of Ukraine and to stipulate the strict requirements of such accountability by laws.

Keywords: public administration, constitutional reform, public administration reform, state bodies of executive power, independent regulatory authorities.

Yuliya Vashchenko, Kijevo nacionalinio Taraso Ševčenkos universiteto Teisės fakulteto Administracinès teisès katedros docentè. Mokslinių tyrimų kryptys: administracinè teisė, energetikos teisè, finansų teisè, žmogaus teisès.

Yuliya Vashchenko, Taras Shevchenko National University of Kyiv, Faculty of Law, Department of Administrative Law, Associate Professor. Research interests: administrative law, energy law, financial law, human rights law. 